\title{
PEMBELAJARAN PENGANTAR FISIKA KUANTUM DENGAN MEMANFAATKAN MEDIA PHET SIMULATION DAN LKM MELALUI PENDEKATAN SAINTIFIK: DAMPAK PADA MINAT DAN PENGUASAAN KONSEP MAHASISWA
}

\author{
Antomi Saregar \\ Pendidikan Fisika, FTK IAIN Raden Intan Lampung; e-mail: antomisaregar@radenintan.ac.id
}

Diterima: 2 Februari 2016. Disetujui: 5 April 2016. Dipublikasikan: April 2016

\begin{abstract}
This study aims to encourage and increase student mastery of concepts on Physics Education Study Program, Quantum Physics subject in wave particle duality, the odd semester of the academic year 2015/2016, using PhET simulations shaped media through a scientific approach. The research method uses a Class Action Research. The results of the implementation of the act of learning physics simulation assisted with the PhET and LKM scientific approach, it can be concluded that: 1) The interest of students during the learning with media-assisted PhET and LKM scientific approach, increased in each cycle. The percentage interest of students in the cycle I until cycle III are 73.33\%, 86.66\% and 90\%; 2) the students mastering of concepts generally increasing, although is not significant. On average the mastery of the concepts of physics students with scientifically-assisted learning of PhET simulations and LKM of the first cycle until. the third cycle in a row is 62.3 ; 79.6; and 80.3.
\end{abstract}

\begin{abstract}
Abstrak: Penelitian ini bertujuan untuk meningkatkan minat dan penguasaan konsep mahasiswa Program studi Pendidikan Fisika, mata kuliah Fisika Kuantum materi dualisme gelombang partikel, semester ganjil tahun ajaran 2015/2016, dengan menggunakan media berbentuk simulasi PhET melalui pendekatan saintifik. Metode penelitian menggunakan Penelitian Tindakan Kelas. Hasil pelaksanaan tindakan pembelajaran fisika dengan pendekatan saintifik berbantu simulasi PhET dan LKM, maka dapat disimpulkan bahwa: 1) Minat mahasiswa selama pembelajaran dengan pendekatan saintifik berbantu media PhET dan LKM, mengalami peningkatan pada setiap siklus. Persentase minat mahasiswa pada siklus I s.d. siklus III berturut-turut adalah $73,33 \%, 86,66 \%$, dan $90 \%$; 2) penguasaan konsep mahasiswa secara umum trennya terus meningkat, walaupun tidak terlalu signifikan. Rata-rata penguasaan konsep fisika mahasiswa dengan pembelajaran saintifik berbantu simulasi PhET dan LKM dari siklus I s.d. siklus III berturut- turut adalah 62,$3 ; 79,6$; dan 80,3 .
\end{abstract}

(C) 2016 Pendidikan Fisika FTK IAIN Raden Intan Lampung

Kata kunci: dualisme gelombang partikel, laboratorium virtual, minat dan penguasaan konsep, pendekatan saintifik, PhET simulation.

\section{PENDAHULUAN}

Fisika merupakan salah satu mata pelajaran dalam rumpun sains yang sangat erat kaitannya dengan kehidupan seharihari manusia. Program Studi (Prodi) Pendidikan Fisika, merupakan salah satu Prodi yang ada dilingkungan Fakultas Tarbiyah dan Keguruan IAIN Raden Intan Lampung. Prodi ini, melaksanakan perkuliahan bagi mahasiswa calon Guru, yang akan mengisi pos-pos sebagai pendidik tingkat satuan pendidikan dibawah Perguruan Tinggi diantaranya,
Guru Fisika di SMA/MA sederajat, maupun Guru IPA di SMP/MTS sederajat. Mahasiswa Program Studi Pendidikan Fisika umumnya menganggap Mata Kuliah Fisika kuantum merupakan salah satu mata kuliah dijenjang perguruan tinggi, yang tergolong sulit untuk dipahami, sehingga mahasiswa sebagian besar kurang berminat dalam proses pembelajaran dikelas. Hal ini berakibat nilai mata kuliah mahasiswa pada semester ganjil tahun pelajaran 
2014/2015 sebagian besar bernilai dengan huruf mutu $C$.

Berdasarkan hasil pre-test diperoleh data bahwa nilai rata-rata pre-test mata kuliah Fisika Kuantum untuk materi dualisme geolmbang partikel, mahasiswa kelas A semester ganjil tahun pelajaran 2015/2016 adalah 67,18 dengan distribusi nilai yang tidak homogen. Fakta hasil obsevasi, bahwa mahasiswa kelas A tersebut, berjumlah 30 mahasiswa. Mahasiswa di kelas tersebut, diantaranya terdapat 21 mahasiswa, tergolong mahasiswa yang kurang aktif dan antusias dalam pembelajaran di kelas. Hal ini disebabkan karena beberapa faktor. Diantara gejala yang tampak pada diri mahasiswa dalam pembelajaran sebagai berikut: 1) Mahasiswa kurang antusias mengikuti pembelajaran; 2) Mahasiswa tidak mampu memahami pelajaran dengan baik ketika dosen mengajar hanya dengan metode ceramah, disisi lain konten materi pelajaran fisika kuantum umumnya berkarakteristik abstrak, dan banyak penurunan persamaan dalam mengkomfirmasi suatu teori. Sedangkan yang tampak pada Dosen saat pembelajaran adalah sebagai berikut: 1) pendekatan pembelajaran dan media yang digunakan kurang bervariasi, dan cederung kurang mampu menjangkau kedalaman materi yang disampaikan; 2) Dosen mendominasi kegiatan belajar mengajar, sehingga berdampak pada tidak terjadinya interaksi yang baik antara Dosen dan mahasiswa dalam proses pembelajaran. (Fen Lin, dkk. 2016) menyatakan, "science educators have the responsibility to explore effective approaches for enhancing students' interest in and enjoyment of learning science, Berarti bahwa seorang Pendidik sains memiliki tanggung jawab dalam mengeksplor pendekatan pembelajaran yang efektif untuk meningkatkan minat siswa dalam belajar.

Kompetensi dasar yang harus dicapai mahasiswa pada materi dualisme gelombang-partikel adalah menganalisis secara konsep kegagalan fisika klasik dan kelahiran fisika kuantum. Adapun untuk mencapai tujuan pembelajaran pada materi dualisme gelombang-partikel, diperlukan pendekatan pembelajaran yang mampu meningkatkan minat dan penguasaan konsep mahasiswa.

Pendekatan dalam pembelajaran memiliki dua jenis menurut Nasution (2013), yaitu: pendekatan pembelajaran yang berorientasi atau berpusat pada siswa (student centered approach) dan pendekatan pembelajaran yang berorientasi atau berpusat pada pendidik (teacher centered approach). Hasil penelitian yang sudah di publikasikan, mengungkap bahwa pendekatan yang berorientasi pada siswa. secara umum lebih efektif dalam meningkatkan minat dan penguasaan konsep peserta didik baik dijenjang perguruan tinggi (mahasiswa), maupung jenjang dibawahnya (siswa). Pendekatan yang dimaksud diantaranya: pendekatan Kontekstual (Saregar, dkk., 2013), dan Pendekatan Saintifik (Siswanto, dkk., 2014; Sari, K.A. 2015).

\section{Kurikulum 2013 merupakan} kurikulum yang secara resmi diterapkan oleh pemerintah mulai tahun 2013 di sebagian sekolah di Indonesia sebagai project percontohan. Kurikulum 2013 menghendaki para peserta didik untuk mempelajari suatu prinsip dan konsep fisika melalui pendekatan saintifik. Dalam hal ini, pendekatan saintifik merupakan pendekatan pembelajaran yang berpusat pada peserta didik. Berdasarkan isi Permendikbud No. 81 A Tahun 2013, tentang pembelajaran dengan menggunkan pendekatan saintifik, peserta didik mengkonstruksi kognitif bagi dirinya sendiri. Pendekatan saintifik dalam pembelajaran merupakan proses ilmiah, dengan langkah-langkah seperti, mengamati (observing), menanya (questioning), mencoba (applying), menalar (sinteshis), dan mengomunikasikan (communication). 
Pendekatan ini dipandang paling sesuai dalam pengembangan minat dan kognitif peserta didik.

Perkembangan instrumen teknologi pendidikan global yang sangat pesat, secara tidak langsung berpengaruh terhadap perkembangan proses kegiatan belajar mengajar (KBM) di Indonesia. Hal ini tampak dengan adanya upaya-upaya pembaharuan pemanfaatan teknologi dalam proses KBM oleh pendidik (dosen dan guru).

Perkembangan $T I K$ menjadi potensi yang sangat besar untuk meningkatkan kualitas pendidikan (Choiron, 2013). Seiring dengan pesatnya perkembangan ilmu pengetahuan dan teknologi, media elektronik dapat menjadi solusi dari kendala yang ditemui oleh pendidik dan peserta didik saat melakukan pembelajaran dengan konten materi yang berkarakteristik abstrak. Percobaan yang sulit dilakukan di laboratorium real, yang umumnya disebabkan minimnya alat-alat praktikum yang memadai, dapat dilakukan menggunakan media laboratorium virtual yang dijalankan dengan komputer. Saregar dkk (2013) mengemukakan bahwa, tujuan penggunaan media berbasis laboratorium virtual adalah agar mempermudah mengkomunikasikan dan membangun konsep tentang konten materi fisika yang bersifat abstrak. Selain itu, peserta didik juga diharapkan mampu mengaplikasikan pengetahuan yang telah diperolehnya dalam kehidupan sehari-hari. Dengan demikian, penguasaan konsep yang dicapai tentunya dapat lebih bermakna dan peserta didik mempunyai tujuan yang nyata dalam mengikuti pembelajaran.

Salah satu aplikasi laboratorium virtual adalah simulasi Physics Education Technology (PhET). The PhET Team (2015) menjelaskan bahwa PhET adalah situs yang menyediakan simulasi pembelajaran fisika, biologi, kimia, dan matematika, yang diberikan secara gratis oleh Universitas Colorado untuk kepentingan pembelajaran di kelas atau dapat digunakan untuk kepentingan belajar individu. Simulasi dirancang secara interaktif, sehingga penggunanya dapat melakukan pembelajaran secara langsung.

Kelemahan dari PhET simulation dalam pembelajaran, yakni belum dilengkapinya dengan lembar kerja mahasiswa (LKM). Mengatasi kelemahan tersebut, terdapat beberapa jurnal yang mempublikasikan hasil pengembangan LKM, dalam pemanfaatan PhET simulation. Diantaranya Sari, dkk. (2015), berhasil mengembangkan lembar kerja peserta didik berbasis PhET dengan hasil validasi sangat menarik, mudah, dan sangat bermanfaat, serta produk efektif sebagai media pembelajaran dengan persentase penguasaan konsep peserta didik lebih dari $80 \%$ telah mencapai kelulusan dalam aspek kognitif dan afektif.

Berdasarkan hal tersebut, simulasi PhET yang dilengkapi dengan lembar kerja mahasiswa (LKM) membuat pembelajaran lebih menarik, sehingga memungkinkan dapat meningkatkan minat peserta didik untuk belajar fisika dan akhirnya diharapkan dapat meningkatkan penguasaan konsep peserta didik.

Efektivitas pemanfaatan PhET sebagai media pembelajaran, sudah pernah dikemukakan dalam beberapa hasil penelitian diantaranya: 1) Adam dkk. (2008) mengemukakan bahwa, simulasi PhET mampu memvisualisasikan dengan baik konsep materi yang awalnya sulit untuk dipahami ketika pembelajaran disajikan dengan metode ceramah; 2) Prihatiningtyas, dkk. (2013), diketahui bahwa hasil belajar dengan menggunakan PhET Simulation lebih efektif dibandingkan dengan KIT sederhana dalam membantu peserta didik memahami konsep untuk konten fisika yang bersifat abstrak. Penggunaan KIT sederhana membutuhkan waktu relatif lebih lama 
karena KIT harus dirangkai terlebih dahulu sebelum siap digunakan, dibandingkan pembelajaran dengan PhET Simulation yang praktis dan menyenangkan; 3) Pembelajaran yang memanfaatkan simulasi PhET diperoleh hasil belajar peserta didik lebih baik daripada peserta didik yang tanpa menggunakan simulasi PhET (Nur, 2013).

Berdasarkan uraian masalah di atas, maka peneliti menganggap perlu melakukan penelitian tindakan kelas (PTK), dengan judul, "Pembelajaran pengantar Fisika Kuantum dengan memanfaatkan Media PhET Simulation dan LKM melalui Pendekatan Saintifik: Dampak Pada Minat dan Penguasaan Konsep Fisika Mahasiswa". Tujuan dari penelitian ini adalah mendeskripsikan tindakan pembelajaran dengan memanfaatkan media PhET melalui pendekatan saintifik dalam meningkatkan minat dan penguasaan konsep aspek kognitif mahasiswa setelah pembelajaran materi dualisme gelombang partikel. Manfaat dari penelitian ini adalah: 1) dapat membantu mahasiswa untuk memahami materi yang sulit untuk dipraktikan dengan media real dan dapat menjadi salah satu alternatif media pembelajaran yang menarik dalam mengaitkan antara teori atau konsep fisika dengan percobaan untuk mencapai penguasaan kompetensi; dan 2) dapat memberikan motivasi bagi pendidik untuk senantiasa terus belajar, guna meningkatkan penguasaan konten dan juga meningkatkan kemampuan mengelola pembelajaran di kelas.

\section{METODE PENELITIAN}

Penelitian ini dilakukan di Program Studi Pendidikan Fisika FTK IAIN Raden Intan Lampung, menggunakan prosedur penelitian tindakan kelas (Classroom Action Research) dengan proses kajian berdaur yang terdiri dari 4 komponen pokok yang dikembangkan oleh Kemmis dan Mc Taggart, yang bersumber dari model PTK Kurt Lewin.

Tahapan awal yang harus dilakukan adalah perencanaan awal (planning), yakni menyiapkan perangkat-perangkat yang akan digunakan dalam pembelajaran, kemudian dilakukan tindakan (acting) dan pengamatan (observing). Selanjutnya dilakukan refleksi (reflecting) terhadap hasil pengamatan serta hasil tindakan yang telah dilakukan, biasanya muncul permasalahan yang perlu mendapat perhatian, sehingga pada gilirannya perlu dilakukan perencanaan ulang, tindakan ulang, pengamatan ulang, serta diikuti pula dengan refleksi ulang. Demikian langkah-langkah kegiatan terus berulang dari siklus satu, dua dan seterusnya, sampai sesuatu permasalahan dianggap teratasi dan memperoleh hasil yang ajeg. Jika hasil siklus ke-dua sama dengan siklus pertama, berarti sudah ada keajegan (Arikunto, 2010).

Proses penelitian tindakan model Kemmis dan Mc Taggart (dalam Arikunto, 2010) dapat visualisasikan seperti gambar 1 berikut,

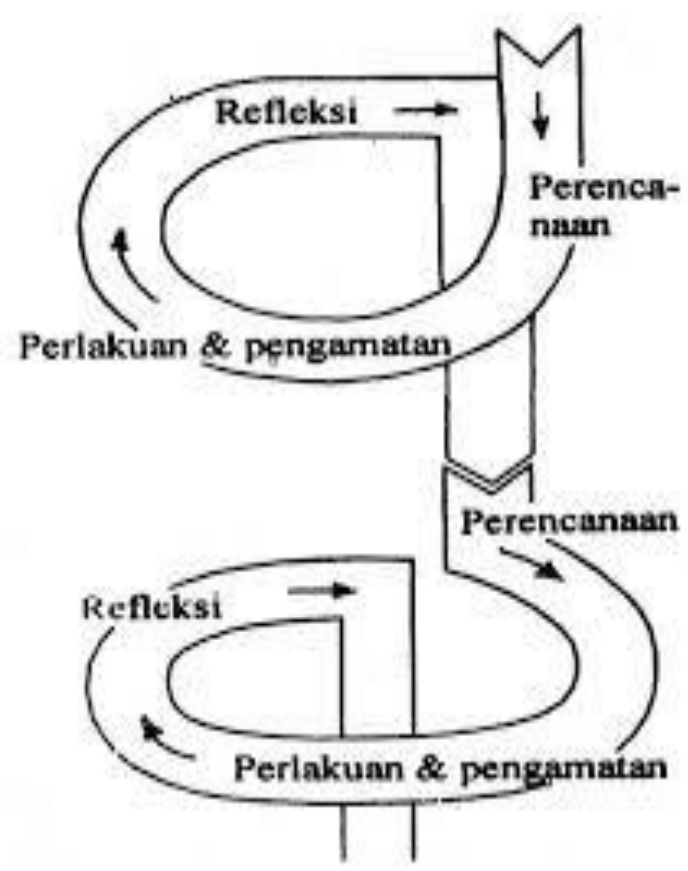

Gambar 1. Siklus Penelitian Tindakan Model Kemmis dan Mc Taggart (dalam Arikunto: 2010) 
Instrumen yang digunakan dalam penelitian ini adalah: 1) Lembar kegiatan mahasiswa. Lembar kegiatan mahasiswa ini dikembangkan dengan menerapkan pendekatan saintifik; 2) Lembar observasi pengelolaan pembelajaran. Lembar observasi pengelolaan pembelajaran terdiri dari: a) Membuka pelajaran, b) Menjelaskan, c) Memberi penguatan, d) Bertanya, e) Media pembelajaran, f) Mengadakan variasi, g) Membimbing diskusi, h) Mengelola kelas, i) Mengevaluasi, j) Menutup pelajaran; 3) Lembar angket minat mahasiswa. Lembar angket minat mahasiswa terdiri dari sejumlah pernyataan yang akan diisi mahasiswa setiap akhir siklus, bertujuan untuk mengukur seberapa besar minat mahasiswa terhadap pembelajaran; 4) Lembar evaluasi penguasaan konsep Lembar evaluasi kognitif mahasiswa terdiri dari tes yang akan mengukur tingkat penguasaan konsep kognitif mahasiswa. Tes berupa soal essay.

Indikator keberhasilan dalam penelitian ini adalah adanya peningkatan minat, dan penguasaan konsep kognitif mahasiswa dari siklus satu ke siklus berikutnya khususnya materi dualisme gelombang-partikel dari satu siklus ke siklus berikutnya.

\section{HASIL DAN PEMBAHASAN}

Pembelajaran dengan Saintifik dimaksudkan untuk meningkatkan minat dan penguasaan konsep fisika mahasiswa. Pada penelitian tindakan kelas ini diusahakan agar minat mahasiswa dapat meningkat dari siklus I s.d siklus III. Minat belajar fisika mahasiswa dengan pendekatan saintifik dari siklus I-III dapat dilihat pada tabel 1 .
Tabel 1. Persentase minat belajar fisika mahasiswa dengan pendekatan saintifik

\begin{tabular}{lcc}
\hline Siklus & $\boldsymbol{\%}$ & Kategori \\
\hline Siklus I & $73,33 \%$ & Tinggi \\
\hline Siklus II & $86,66 \%$ & Tinggi \\
\hline Siklus III & $90,00 \%$ & Tinggi \\
\hline
\end{tabular}

Berdasarkan tabel 1 diketahui bahwa secara umum minat belajar mahasiswa dalam kategori tinggi, terjadi peningkatan yang signifikan, pesentase minat belajar mahasiswa dari siklus I ke siklus II, yakni meningkat $13,33 \%$ (4 mahasiswa yang minatnya meningkat). Sedangkan pada siklus III hanya meningkat $3,33 \%$ (hanya 1 mahasiswa yang minatnya meningkat).

Berdasarkan pelaksanaan pada siklus I, mahasiswa merasa senang dan antusias mengikuti pembelajaran materi efek foto listrik menggunakan pendekatan saintifik dengan media PhET dan LKM. Langkah-langkah pendekatan saintifik, mampu menuntun mahasiswa untuk aktif terlibat langsung dalam proses mengembangkan pengetahuan, kemampuan berpikir, dan keterampilan menggunakan pengetahuan mahasiswa melalui interaksi langsung dengan sumber belajar, yang dirancang dalam silabus dan RPP layaknya praktikum menggunakan alat praktikum (KIT) laboratorium real. Hal tersebut dapat terjadi, karena pendekatan saintifik, dalam praktiknya, menstimulus mahasiswa melakukan kegiatan mengamati, menanya, mengumpulkan informasi, menalar, dan akhirnya mahasiswa mampu mengomunikasikan hasil pengalaman belajarnya.

Minat belajar fisika mahasiswa dalam pembelajaran dengan pendekatan saintifik menggunakan PhET Simulation dan LKM, pada siklus II mengalami peningkatan minat cukup signifikan, meski sebelumnya beberapa mahasiswa merasa sedikit bosan dengan 
pembelajaran yang selalu dilakukan dengan kerja kelompok. Bagi mahasiswa yang jarang mengungkapkan pendapat, dengan pembelajaran seperti ini dirasakan sulit. Namun, hal ini berangsur dapat diatasi oleh peneliti dengan cara memberikan perlakuan khusus pada mahasiswa tersebut seperti: 1) memberi stimulan pertanyaan seputar materi yang dibahas; 2) peneliti mendengarkan dengan antusias terkait jawaban mahasiswa tersebut; 3) memberi hadiah dan motivasi, agar mahasiswa tersebut terus aktif dikelompoknya. Tidak hanya itu, saat diskusi kelompok berlangsung, peneliti melibatkan mahasiswa-mahasiswa yang pasif untuk bertanya maupun menjawab pertanyaan sehingga hasilnya pun cukup memuaskan, hal ini terlihat dari meningkatnya minat mahasiswa dalam pembelajaran pada siklus kedua ini.

Minat belajar fisika mahasiswa juga meningkat pada siklus III sekitar 3,33\%. Hal ini terjadi karena mahasiswa sudah cukup terbiasa pembelajaran dengan pendekatan saintifik menggunakan media PhET dan LKM. Peningkatan minat belajar dari siklus I ke siklus II, dengan selisih hanya $3,33 \%$, menunjukkan bahwa sudah terjadi kemantapan peningkatan minat belajar pada mahasiswa. Hal tersebut menjadi dasar bagi peneliti, bahwa penelitian tindakan sudah cukup pada siklus III saja.

\section{Dekripsi Pengelolaan Pembelajaran.}

Pengelolaan pembelajaran dengan pendekatan saintifik menggunakan media PhET dan LKM oleh peneliti meliputi: a) Membuka pelajaran, b) Menjelaskan, c) Memberi penguatan, d) Bertanya, e) Media pembelajaran, f) Mengadakan variasi, g) Membimbing diskusi, h) Mengelola kelas, i) Mengevaluasi, j) Menutup pelajaran. Pengelolaan ini direfleksikan pada setiap akhir siklus dan direkomendasikan untuk dilakukan perbaikan pada siklus berikutnya, sehingga pembelajaran dapat dilakukan dengan baik dan teratur.

Berdasarkan pelaksanaan pada siklus I, peneliti belum dapat melaksanakan seluruh aspek yang diamati. Pada pelaksanaannya 66,25\% baik, namun belum sempurna, dan masih banyak yang perlu diperbaiki.

Beberapa hal yang perlu diperbaiki meliputi: a) kemampuan peneliti dalam membimbing diskusi, sehingga presentasi dua kelompok terakhir suasana kelas sedikit gaduh; b) peneliti kurang memberikan penguatan atas konsep materi yang disampaikan, sesaat setelah simulasi PhET selesai di sajikan; c) evaluasi pada pertemuan ke-dua belum sempat dilakukan karena waktu tidak memungkinkan. Sebagai gantinya evaluasi dilakukan pada pertemuan ke-3.

Proses pelaksanaan pembelajaran pada siklus II diusahakan agar pengelolaan pembelajaran yang dilakukan peneliti lebih baik dibandingkan siklus I. Hasilnya, pada siklus II sudah mampu mengelola pembelajaran dengan cukup baik, dengan persentase $81,25 \%$. Diskusi saat presentasi berlangsung sudah berjalan dengan baik sesuai dengan harapan peneliti, dan peneliti sudah baik dalam memberikan penguatan atas konsep materi yang disampaikan, sesaat setelah simulasi PhET selesai di sajikan.

Terjadi peningkatan pengelolaan pembelajaran pada siklus III dengan persentase $87,5 \%$ kategori baik. Peneliti sudah mampu memaksimalkan pelaksanaan pengelolaan pembelajaran dengan baik, sehingga mengakibatkan meningkatnya minat belajar mahasiswa.

\section{Deskripsi Penguasaan Konsep Mahasiswa dengan Pendekatan Saintifik}

Berdasarkan data penguasaan konsep mahasiswa, diperoleh gambaran rata-rata evaluasi penguasaan konsep fisika mahasiswa yang selalu meningkat dari siklus ke siklus walaupun hasilnya 
tidak signifikan. Data evaluasi penguasaan konsep fisika mahasiswa dari siklus I s.d. III dapat dilihat pada tabel 2

Tabel 2. Data penguasaan konsep fisika mahasiswa dari siklus I-III

\begin{tabular}{lcl}
\hline Siklus & $\begin{array}{l}\text { Rata-rata } \\
\text { penguasaan } \\
\text { konsep }\end{array}$ & Kategori \\
\hline SiklusI & 62,3 & Sedang \\
\hline Siklus II & 79,6 & Tinggi \\
\hline Siklus III & 80,3 & Tinggi \\
\hline
\end{tabular}

Pada siklus I, soal yang dianggap sukar adalah soal-soal yang berkaitan dengan konsep efek foto listrik hal ini dikarenakan konsep dasar mahasiswa mengenai perilaku partikel rendah. Selain itu mahasiswa juga tidak terbiasa jika dilakukan post-test secara langsung pada akhir pembelajaran.

Mahasiswa sudah mulai menguasai konsep efek foto listrik pada siklus II, tetapi masih ada beberapa mahasiswa yang merasa bingung dengan perbedaan cahaya sebagai partikel pada saat simulasi PhET di jalankan, maupun saat dijelaskan dengan gambar. Namun rata-rata penguasaan konsep pada siklus ini meningkat.

Sedangkan pada siklus III penguasaan konsep mahasiswa juga mengalami peningkatan, hal ini dikarenakan meningkatnya minat mahasiswa. Selain itu, mahasiswa juga sudah cukup memahami perbedaan cahaya sebagai partikel dan cahaya sebagai gelombang ketika praktikum maupun dijelaskan dengan gambar walaupun masih ada beberapa mahasiswa yang masih menjawab pertanyaan secara tidak ilmiah.

\section{SIMPULAN DAN SARAN}

Hasil pelaksanaan tindakan pembelajaran fisika dengan pendekatan saintifik berbantu simulasi PhET dan LKM, maka dapat disimpulkan bahwa: 1) Minat mahasiswa selama pembelajaran dengan pendekatan saintifik berbantu media PhET dan LKM, mengalami peningkatan pada setiap siklus. Persentase minat mahasiswa pada siklus I s.d. siklus III berturut-turut adalah 73,33\%, 86,66\%, dan $90 \%$; 2) Penguasaan konsep fisika mahasiswa secara umum dalam kriteria sedang, yang terus meningkat walaupun tidak terlalu signifikan. Rata-rata penguasaan konsep fisika mahasiswa dengan pembelajaran saintifik berbantu simulasi PhET dan LKM dari siklus I s.d. siklus III berturut- turut adalah 62,3; 79,6; dan 80,3 .

\section{Saran}

Berdasarkan pelaksanaan tindakan yang dilakukan oleh peneliti disarankan dalam penelitian ini sebaiknya: 1) Dalam pembelajaran, jika mahasiswa tidak mampu mengungkapkan isu sains yang berkaitan dengan materi, pendidik hendaknya membimbing mahasiswa dengan pertanyaan-pertanyaan yang besifat responsif. Jika mahasiswa masih belum bisa menjawab, pendidik dapat memunculkan isu sains yang berkaitan dengan materi; 2) pemanfaatan PhET simulation sebagai media pembelajaran berbasis laboratorium virtual, hendaknya disertai dengan lembar kerja, dengan harapan peserta didik lebih mudah memahami maksud dari simulasi tersebut.

\section{DAFTAR PUSTAKA}

Adams, W. K., Reid, S., LeMaster, R., McKagan, S. B., Perkins, K. K., Dubson, M., \& Wieman, C. E. (2008). A study of educational simulations part II-interface design. Journal of Interactive Learning Research, 19(4), 551.

Arikunto, S., \& Jabar, C. S. (2006). 2010. Prosedur Penelitian Suatu Pendekatan Praktik (Edisi Revisi). 
Choiron, M. (2013). Memanfaatkan Media ICT dalam Pembelajaran (Online):

(http://www.teknologi.kompasiana.c om/terapan/2013/11/28/memanfaatk an-media-ict-dalam-pembelajaran 614758.html. diakses 3 Maret 2015).

Depdikbud. (2013). Permendikbud Nomor $81 A$ Tahun 2013 tentang Implementasi Kurikulum. Jakarta: Departemen Pendidikan dan Kebudayaan.

Lin, S. F., \& Lin, H. S. (2016). Learning nanotechnology with texts and comics: The impacts on students of different achievement levels. International Journal of Science Education, 38(8), 13731391.

Nasution, K. (2013). Aplikasi Pembelajaran dalam Perspektif Pendekatan Saintifik. Online): (http://www. sumut. kemenag. go. id/file/file/TULISANPENGAJAR/nqt x1392172430. pdf. diakses 19 Juni 2014).

Nur, M. H. R. (2013). Pengembangan Perangkat Pembelajaran Fisika yang Bersinergi dengan Media Lab. Virtual PhET pada Materi Sub Pokok Bahasan Fluida Bergerak di MAN 2 Gresik. Jurnal Inovasi Pendidikan Fisika, 2(3), 162-166.

Prihatiningtyas, S., Prastowo, T., \& Jatmiko, B. (2013). Imlementasi Simulasi PhET dan Kit Sederhana untuk Mengajarkan Keterampilan Psikomotor Siswa pada Pokok Bahasan Alat Optik. Jurnal Pendidikan IPA Indonesia, 2(1).

Saregar, A., Sunarno, W., \& Cari, C. (2013). Pembelajaran Fisika Kontekstual Melalui Metode Eksperimen Dan Demonstrasi Diskusi Menggunakan Multimedia Interaktif Ditinjau Dari Sikap Ilmiah Dan Kemampuan Verbal Siswa. Jurnal Inkuiri, 2(02).
Sari, A. K., Ertikanto, C., \& Suana, W. (2015). Pengembangan LKS Memanfaatkan Laboratorium Virtual pada Materi Optik Fisis dengan Pendekatan Saintifik. Jurnal Pembelajaran Fisika, 3(2).

Siswanto, I. Kaniawati, A. \& Suhandi. (2014). Penerapan Model Pembelajaran Pembangkit Argumen Menggunakan Metode Saintifik Untuk Meningkatkan Kemampuan Kognitif dan Keterampilan Berargumentasi Siswa. Jurnal Pendidikan Fisika Indonesia 10 (2) (2014) 104-116.

The PhET Team. (2015). PhET (Intective Simulations). (Online): http://www. PhET.colorado.edu/in/. diakses 3 Maret 2015). 